\title{
THE ROLE OF CORRECTIVE FEEDBACK ON ACADEMIC WRITING PERFORMANCE: EFL STUDENTS' PERCEPTIONS
}

\author{
Sri Wahyuningsih \\ Institut Agama Islam Negeri Kudus \\ wahyuningsih@iainkudus.ac.id
}

\begin{abstract}
In the context of higher education, corrective feedback plays a crucial part in academic writing. This paper, therefore, aims to explore the role of corrective feedback on the academic writing performance of EFL students at State Islamic Institute of Kudus. The study employed a qualitative research. In order to gather data, the writer interviewed the students about the perception of the use corrective feedback in enhancing their performance in academic writing. In addition, observation and documentation were conducted to get detail information. The result showed that corrective feedback including the aspects of providing and receiving feedback has led to better improvement in students' academic writing performance. Indeed, they become more confident in performing their academic writing task. Further, through corrective feedback, students are highly pursued to give more comments regarding the performance of their peers in academic writing. In addition, lecturers merely give clarifications towards the corrective feedbacks in academic writing class by provoking question and answer to promote the students' critical thinking skills.
\end{abstract}

Keywords: Academic Writing, Corrective Feedback, EFL Students' Perceptions, Performance.

Academic writing plays a crucial role in EFL students' English acquisition. In accordance with it, they may have barriers or challenges in their academic writing performance in which they are highly enhanced to adopt conventions of style, references and layout. Furthermore, the development of discourse competence including knowledge of cohesion and coherence in the text and the ability to establish different types of knowledge is required for the novice writer (Wahyuningsih, 2018a, p. 16). Besides, the crucial aspect that may contribute to develop the academic writing is the need of socialcultural model including creating a supportive environment consisting of more knowledgeable writers as models, advocating writing approximation as success, applying supportive dialogue shaping the learners' thinking as they write, developing strategies of planning in creating test, using editing and revising strategies, publishing and sharing writing with real environment and audiences(van Kraayenoord, Miller, Moni, \& Jobling, 2009, p. 25)

As a matter of fact, an error may take place among EFL students since it is not their mother tongue. Additionally, error has become a natural part of learning (Tasdemir \& Arslan, 2018, p. 2).Referring to it, 
students are highly engaged in the process of academic writing consistently. Nevertheless, engaging students in the process of teaching and learning writing continuously and providing written supportive feedback has $\ll \mid 14$ not yet been emphasized (Bostanci \& Çavuşoğlu, 2018, p. 2). In addition, feedback should be emphasized on action and connected to goals reinforcing a better performance (Haffling, Beckman, \& Edgren, 2011, p. 349).Therefore, providing corrective feedback plays an important role in correcting errors particularly in teaching and learning process since teaching is not a matter of transferring knowledge but the understanding the progress of students in teaching and learning process. Considering it, it is crucial for students to comprehend their progress through feedback by the teachers.

A number of studies related to giving feedback in educational settings have been undertaken by some previous researchers. Feedback has been a dynamic process involving the educators and the students to gain positive impacts through enhancing repetition and correcting errors or negative ones through enhancing a change (Algiraigri, 2014, p. 1). In addition, constructive feedback encourages awareness of the skill education and courses development(Cushing, Abbott, Lothian, Hall, \& Westwood, 2011, p. 105). In accordance with teaching writing, EFL students highly need written feedback and assessment through some courses regarding the process of teaching writing (Bostanci\& Çavuşoğlu, 2018, p. 3). Additionally, giving peer feedback considerably benefits to students' writing performance as it arouses the task-specific processes and criteria (Huisman, Saab, van Driel, \& van den Broek, 2018, p. 956).In speaking class, the hypothesis of interaction reports that feedback gained from interaction could be crucial for language learning (Zhai \& Gao, 2018, p. 2).

Likewise, corrective feedback is essentially enhanced in teaching academic writing to EFL students at State Islamic Institute of Kudus (IAIN) Kudus considering that English is not their mother tongue. Additionally, they find a number of barriers in academic writing class. These include limited exposures of English vocabulary, lack of both intensive and extensive reading, lack of proficiency in structure, lack of references and so on. Consequently, this may lead to provide corrective feedback through the comments of lecturers and students in order to support students' academic writing performance. Referring to it, this article specifically explores the importance of providing corrective feedback to students in academic writing class in order to enhance their academic writing performance. Further, it describes the ways of corrective feedback used in academic writing class.

\section{METHODS}

This study was conducted as a qualitative research. In relation to a qualitative research, it mainly tries to probe deeply into the research setting to obtain in depth understanding about the way things are, why they are that way, and how the participants in the context perceive them (Gay, Mills, \& Airasian, 2012).Data were gathered through observation, documentation and interview to six EFL students at State Islamic Institute of Kudus (IAIN) Kudus relevant to their perception to the use of corrective feedback in enhancing their academic writing performance. Furthermore, documentation and observation were conducted to explore the experience and process of teaching academic writing.

\section{DISCUSSION}


Perceptions of EFL Students to the Role of Corrective Feedback on Academic Writing Performance

In accordance with the academic writing skill, the students at State Islamic Institute of Kudus have actually been diverse in terms of linguistic and cognitive development. Additionally, their academic writing skill highly needs improvement which can be enhanced by providing corrective feedback among lecturers and students. Having interviewed some EFL students, they perceive that corrective feedback have highly better impacts and benefits on their academic writing performance.

First, corrective feedback has given meaningful insights about academic writing. Based on the interview, it indicates that most EFL students at State Islamic Institute of Kudus perceive that corrective feedback has given knowledgeable understanding related to academic writing. Additionally, they will learn how to make corrections of their peer works. Interestingly, lecturers are merely giving some clues regarding the errors or mistakes made by the students. Then, students are motivated to give feedback by making corrections towards their peer works. In the end, lecturers are giving clarifications as the result of corrective feedback. Referring to it, corrective feedback is made by both students and lecturers during the teaching and learning process.

There are many aspects of insightful knowledge they obtain from corrective feedback. First, students are able to comprehend elements of academic writing such as the importance of cohesion and coherence. In this sense, students present their work of academic writing in front the class. Meanwhile, their peers are asked to give comments related to the work of academic writing as a corrective feedback.
Further, lecturer also gives comments related to the students work as the result of clarifications. Thus, the result of corrective feedback is expected to enhance more crucial revisions. Second, students are able to elicit the feedback especially on content and structure which can be perceived as more appropriate revisions. This finding is in accordance with Huisman, Saab, van Driel, \& van den Broek (2018, p. 957)reporting that feedback can function to provide adequacy of students' perception and their effort to revise their work. Considering this, corrective feedback can be beneficial contributions on meaningful aspect of the text covering content, structure and style. Further, it contributes on special function including analytical and evaluative revisions. This has been proved by the comments of EFL students at State Islamic Institute of Kudus:

"Corrective feedback has given me a lot of meaningful knowledge related to academic writing. The corrective feedback is provided by both students and lecturers in which students are enhanced to give their comments related to their friend's work including error and mistakes in order to suggest some revisions. Besides, a lecturer gives a clarification through some comments of the student's work. Therefore, the comments of both lecturers and students can contribute to evaluative revisions" (Syafaah, May 2019).

The above description is also supported by another student highlighting that corrective feedback has contributed to special functions which cover analytical and evaluative revisions. 
"Corrective feedback is beneficial on giving knowledge and elements needed in academic writing. The lecturer gives her comments toward student's work. Interestingly, she also motivates other students to give their comment toward their friends' work as corrective feedback. In this sense, corrective feedback provides evaluative and analytical revisions. Indeed, the content, structure and style of the student's writing are also evaluated in the process of corrective feedback" (Aini, May 2019).

Along with the above comments, it denotes that corrective feedback is perceived by the students as the adequacy and insightful knowledge based on the peer and lecturer feedback associated with the students' subsequent writing performance. Thus, students are more inclined to apply the corrective feedback for correcting and revising their academic writing performance.

Second, corrective feedback is useful in giving error identification toward the students' writing performance. Generally, EFL students have made errors in their academic writing work. The lecturer, therefore, needs to correct it so that the academic writing of students can be meaningful and understandable. A long with the correction, corrective feedback plays a crucial role in giving error identification toward the student's academic writing performance. Besides, the corrective feedback also provides error diagnosis and better revisions. It has been revealed by some students at State Islamic Institute of Kudus.

"I find some problems in academic writing. These cover problem in content of writing, structure such as tenses, limited academic vocabularies, and style in academic writing. Generally, it is difficult to create a meaningful text in which it requires the skill of connecting the sentences through coherence and cohesion. Furthermore, the acquisition of making paraphrase is important to avoid plagiarism. Indeed, it is not easy for doing a good paraphrase" (Fahmi, May 2019)

The above elaboration is in line with another student who reports that errors frequently take place in performing academic writing.

"I often make errors in academic writing. Further, it is difficult to create a good text. Somehow, it is not easy to express ideas in academic writing considering my limitation in reading and listening academic English texts. As a result, my exposure of vocabulary is so limited. In addition, a good paraphrasing is needed in academic writing. This becomes challenges for me. In fact, doing a paraphrase is not really easy since we are demanded to write using our own sentences" (Nuha, May 2019).

In relation to providing corrective feedback, the lecturer is usually giving feedback through both explicit and implicit feedback. In this sense, implicit feedback is provided by giving some clues in errors made by studentsand the ways of correcting those errors. Meanwhile, explicit feedback is given when most students are having difficulties in giving corrective feedback toward their peer works. Considering it, the importance of giving a mixture of implicit 
and explicit feedback in academic writing is considerably effective (Banaruee, KhatinZadeh, \& Ruegg, 2018, p. 4).

Third, corrective feedback motivates students in better academic writing. In academic writing class, students are motivated to have a better academic writing performance. This can be achieved by showing a number of research articles from reputable journals to students. Consequently, they have wider knowledge about how to write a better academic writing. Additionally, they will be aware of the elements, content, structure and style included in academic writing. Interestingly, it can be one of the ways to provide corrective feedback in which students have more awareness and motivation in performing the better academic writing. Regarding this, students will be more enthusiastic in achieving a better academic writing performance. Indeed, they become more familiar about composing a good abstract, introduction, method, result, discussion, and conclusion. Surprisingly, students are fostered to be aware of using reference management such as Zotero and Mendeley in order to facilitate them in managing citation. The role of corrective feedback in motivating students in academic writing class has been proved by the comments of students.

"I become more motivated in learning academic writing through the corrective feedback. In the process of giving corrective feedback, the lecturer has shown us a number of examples of research articles published by some reputable journals. Consequently, we become more aware of how to write a research paper including the content of research, structure or tenses, and style in academic writing. The corrective feedback, therefore, has been able to arouse us to perform a better academic writing" (Nuralim, May 2019).

Another student has revealed the same thing that she is more fostered in academic writing class through the corrective feedback provided by the lecturer and her friends.

"I get wider knowledge and motivation in performing a better academic writing. In fact, there are some crucial elements needed in academic writing. In addition, the reference management is crucially used in citation. Interestingly, I become familiar with Zotero and Mendeley. They have been meaningful in writing an international paper. In addition, it facilitatesme in storing some files and has a better citation" (Hanum, May 2019).

Based on the above elaboration, it could be clearly seen that most students are highly motivated to improve their academic writing performance since they have obtained the corrective feedback in academic writing class. This finding is strengthened by Banaruee et al., (2018, p. 8) advocating that direct corrective feedback plays a significant contribution on the writing performance of EFL learners. It seems that corrective feedback could be an effective tool for enhancing them to recognize errors in writing and to revise these errors. 
Fourth, corrective feedback promotes the students' critical thinking skill. The finding of the interview indicates that corrective feedback presumably has been

$\ll$ | 18 able to promote EFL students to increase their critical thinking skills. It should be noted that in the process of corrective feedback, students are highly pursued by the lecturer to give their comments toward their peer's work. They should criticize the article written by their peers. Additionally, they surely focus on commenting the aspects of writing such as the content and structure. Moreover, they are freely to identify the errors made by their peers and provoke suggestible revisions. This, therefore, promotes them to think critically when suggesting ideas and revisions. In addition, students are strongly motivated to express their argumentative feedback and a detail example and revision as corrective feedback. This is in line with Noroozi \& Hatami (2018, p. 4) arguing that providing argumentative comments can contribute to corrective feedback. In other words, the immediate corrective feedback gives the better impact on EFL students' performance in authentic setting (Tasdemir \& Arslan, 2018, p. 3). This elaboration is nicely proved by the comments of the students.

"In academic writing class, we are encouraged to express our ideas and comments related to our friends' work. We should find some errors made by our friends in writing and propose some suggestible revisions. We should think critically towards the article written by our friends. In addition, we should give immediate corrective feedback when our friends show their academic writing works in front of the class. Thus, this makes all students are motivated to give comments and increase their critical thinking skills" (Syafaah, May 2019).

This is in conjunction with another student, Nuha, who claims that the demand of giving correcting feedback has made him think critically. As a matter of fact, before being pursued by the lecturer to give corrective feedback, students are less motivated to give their comments since they have no ideas. Surprisingly, being motivated by the lecturer to give corrective feedback towards their peer's works, students are more enthusiastic in giving their comments as corrective feedback. In addition, this encourages them to frequently read some research articles from international journals. The role of corrective feedback in contributing the students' critical thinking skills is also strengthened by Marbouti, Mendoza-Garcia, Diefes-Dux, \& Cardella (2019, p. 183) noting that students were assigned to identify a critical need and propose the solution.

\section{Some Barriers of Giving Corrective Feedback in Academic Writing Class}

Along with corrective feedback, there are barriers in the process of giving corrective feedback based on the observation. These include some students have difficulties expressing their ideas to give comments and feedback. This is due to their lack exposure of reading research articles in academic writing context. Consequently, it may hinder them in revealing their critical argumentation towards their peer's works. Unfortunately, some students have not been able to identify the errors and propose some better revisions 
in acceptable ways. Thus, it may discourage them to comment their peer's work as corrective feedback. The next barrier in giving corrective feedback in academic writing is problem in paraphrasing the content appropriately. It may be caused by the lack of exposure in English, discourse patterns, and structure (Wahyuningsih, 2018b, p. 111).In fact, the ability to paraphrase a text is indeed crucial in academic writing. The last barrier is the process of corrective feedback in academic writing classroom takes more time so that it needs several meetings when discussing a number of texts. Additionally, the timing of giving feedback and situation of students should be considered in corrective feedback (Tasdemir \& Arslan, 2018, p. 2).

\section{CONCLUSION}

This study explicitly explores the perceptions of EFL students at State Islamic Institute of Kudus in accordance with the role of corrective feedback in academic writing classroom. Referring to the result of interview, observation and documentation, it reveals that the majority of students have positive attitudes towards the use of corrective feedback in their academic writing performance. First, corrective feedback has given meaningful insights about academic writing. Second, corrective feedback is useful in giving error identification toward the students' writing performance. Third, corrective feedback motivates students in better academic writing. Fourth, Corrective feedback promotes the students' critical thinking skill. However, some barriers are also encountered in the process of giving corrective feedback in academic writing classroom. These include the difficulty of students in expressing their ideas when giving comments and feedback, the lack ability in paraphrasing the content of text appropriately and the long timing of giving corrective feedback. It should be noticed that this paper has focused on the perception of EFL students at State Islamic Institute of Kudus in the use of corrective feedback in their academic writing performance. It is highly suggested that future researchers conduct such studies in other fields from various disciplines and perspectives. By completing this study, we would mainly get insights on how the corrective feedback may contribute to the academic writing performance among EFL students.

\section{REFERENCES}

Algiraigri, A. H. (2014). Ten tips for receiving feedback effectively in clinical practice. Medical Education Online, 19, 25141. https://doi.org/10.3402/meo.v19.25141

Banaruee, H., Khatin-Zadeh, O., \& Ruegg, R. (2018). Recasts vs. direct corrective feedback on writing performance of high school EFL learners. Cogent Education, 5(1), 1-23. https://doi.org/10.1080/2331186X.2018.1455333

Bostanci, H. B., \& Çavuşoğlu, Ç. (2018). Pen-and-paper or online? An academic writing course to teacher-trainees. Cogent Education, 5(1), 1-15. https://doi.org/10.1080/2331186X.2018.1482606

Cushing, A., Abbott, S., Lothian, D., Hall, A., \& Westwood, O. M. R. (2011). Peer feedback as an aid to learning - What do we want? Feedback. When do we want it? Now! Medical 
Teacher, 33(2). https://doi.org/10.3109/0142159X.2011.542522

Gay, L. R., Mills, G. E., \& Airasian, P. W. (2012). Educational Research Competencies for Analysis and Applications Tenth Editions. Boston: Pearson Prentice Hall.

Haffling, A. C., Beckman, A., \& Edgren, G. (2011). Structured feedback to undergraduate medical students: 3 years' experience of an assessment tool. Medical Teacher, 33(7).

<| $20 \quad$ https://doi.org/10.3109/0142159X.2011.577466

Huisman, B., Saab, N., van Driel, J., \& van den Broek, P. (2018). Peer feedback on academic writing: undergraduate students' peer feedback role, peer feedback perceptions and essay performance. Assessment and Evaluation in Higher Education, 43(6), 955-968. https://doi.org/10.1080/02602938.2018.1424318

Marbouti, F., Mendoza-Garcia, J., Diefes-Dux, H. A., \& Cardella, M. E. (2019). Written feedback provided by first-year engineering students, undergraduate teaching assistants, and educators on design project work. European Journal of Engineering Education, 44(1-2), 179-195. https://doi.org/10.1080/03043797.2017.1340931

Noroozi, O., \& Hatami, J. (2018). The effects of online peer feedback and epistemic beliefs on students' argumentation-based learning. Innovations in Education and Teaching International, 3297, 1-10. https://doi.org/10.1080/14703297.2018.1431143

Tasdemir, M. S., \& Arslan, F. Y. (2018). Feedback preferences of EFL learners with respect to their learning styles. Cogent Education, 5(1), 1-17. https://doi.org/10.1080/2331186X.2018.1481560

van Kraayenoord, C. E., Miller, R., Moni, K. B., \& Jobling, A. (2009). Teaching writing to students with learning difficulties in inclusive English classrooms: Lessons from an exemplary teacher. English Teaching, 8(1), 23-51.

Wahyuningsih, S. (2018a). Challenges and Opportunities of Teaching Academic Writing Skills: A Case Study of Students at IAIN Kudus. Edulingua, 5(1), 15-24.

Wahyuningsih, S. (2018b). Empowering Academic Writing Skills in Millennial Era: The Role of English Program for Bidikmisi Students. In The 2nd National TELCECON (Teaching, Linguistics, Culture, and Education Conference) "Pendidikan di Era 4.0 (pp. 108-114). Universitas Muria Kudus.

Zhai, K., \& Gao, X. (2018). Effects of corrective feedback on EFL speaking task complexity in China's university classroom. Cogent Education, 5(1), 1-13. https://doi.org/10.1080/2331186X.2018.1485472 
